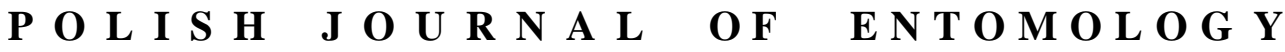

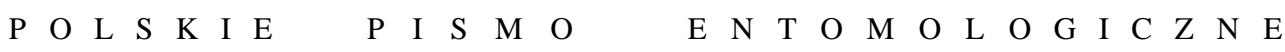

VOL. 85: 419-428

Lublin

31 December 2016

DOI: $10.1515 /$ pjen-2016-0026

\section{The first records of Nemapogon gliriella (HEYDEN, 1865) (Lepidoptera, Tineidae) in Poland: a fungivorous species reared from sporocarps of Stereum hirsutum (WILLD.) PERS. and S. rugosum Pers. (Fungi: Basidiomycota)}

\author{
XAVIER DOBRZAŃSKI ${ }^{1}$, ŁUKASZ DAWIDOWICZ ${ }^{2}$, GRZEGORZ KAROL \\ WAGNER $^{2}$, TOMASZ JAWORSKI ${ }^{3 *}$ \\ ${ }^{1}$ Odrzańska 17/5, 50-113 Wrocław, Poland \\ ${ }^{2}$ Department of Zoology, Maria Curie-Skłodowska University, Akademicka 19, \\ 20-033 Lublin, Poland \\ ${ }^{3}$ Department of Forest Protection, Forest Research Institute, Sękocin Stary, \\ Braci Leśnej 3, 05-090 Raszyn, Poland
}

\begin{abstract}
The paper presents the first records of the tineid moth Nemapogon gliriella in Poland. Eleven specimens were reared from sporocarps of Stereum hirsutum and S. rugosum growing on dead oak and hazel wood. Issues concerning morphological similarity with other species in the genus Nemapogon are briefly discussed. The basic ecological characteristics of the species are presented.
\end{abstract}

KEY WORDS: saproxylic insects, fungus moths, dead wood, fruiting bodies, wood-decaying fungi, oak woodlands, acidophile oak forest.

\section{INTRODUCTION}

The genus Nemapogon SCHRANK, 1802 includes many fungivorous species, often very similar in external morphology (ROBINSON 2009, GAEDIKE 2015). They are typically small, but polymorphic in size even within one species. The forewings are usually grey or brown with white, black and sandy spots, whereas the hindwings are light-to-dark grey. The

\footnotetext{
*Corresponding author: t.jaworski@ibles.waw.pl
} 
correct identification of particular species often requires examination of the genitalia structures. Although adult moths can be attracted to artificial light sources, the collection of inhabited wood-decaying fungi seems to be the most effective method of recording these insects in a given area (e.g. JAWORSKIet al. 2014).

So far, 10 species of the genus Nemapogon have been reported from Poland (ŚLIWIŃSKI 2000). The aim of this article is to present the first records of Nemapogon gliriella (HEYDEN, 1865) in Poland.

\section{Acknowledgements}

The authors thank Dr Andrzej SzCZEPKOWSKI (Warsaw University of Life Sciences) for identifying the fungi.

\section{MATERIALS AND METHODS}

The specimens were collected during research on polypore fungi in forests along the Oder valley and in the Roztocze National Park. Sporocarps (fruiting bodies) of wooddecaying fungi inhabited by moth larvae were collected and then stored in plastic boxes. The reared adult moths (Fig. 1) were preserved and then identified on the basis of external morphology and genitalia structure in accordance with the generally accepted methodology.

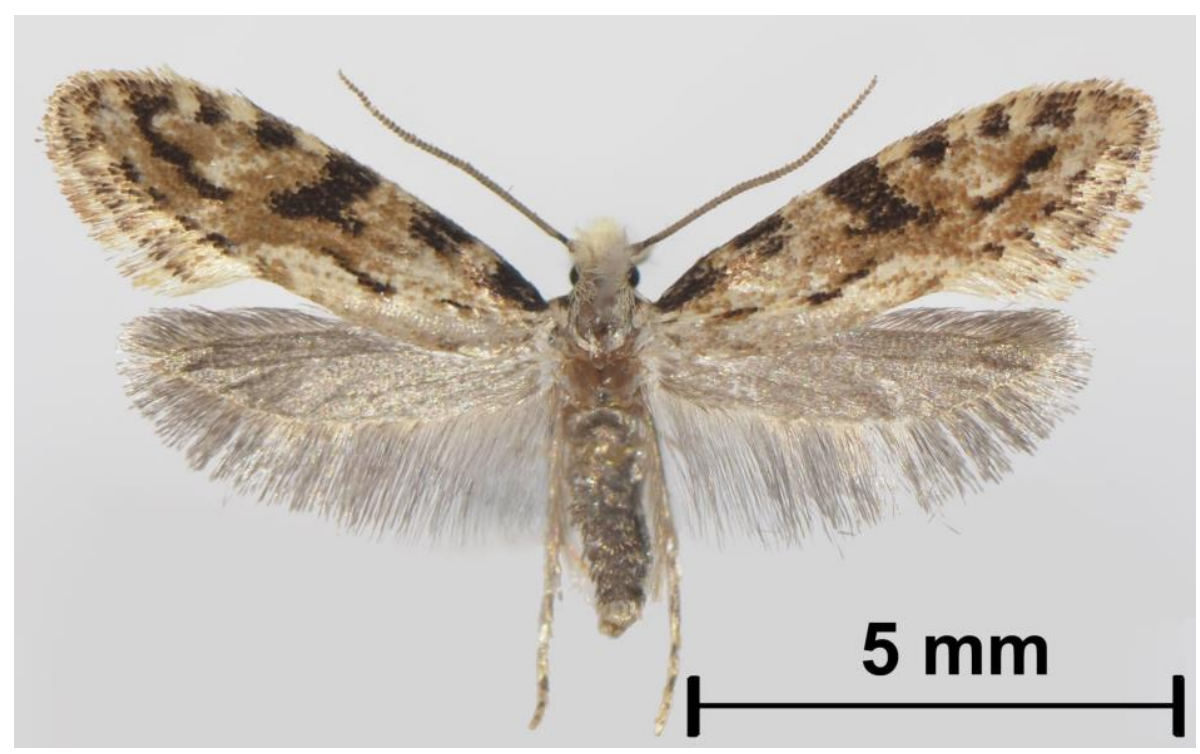

Fig. 1. Adult Nemapogon gliriella reared from a sporocarp of Stereum hirsutum. 


\section{RESULTS}

Nemapogon gliriella was recorded at the following localities:

- Janików [UTM: XS64], 15-17.02.2015, 4 exx., ex larvae, cult. Stereum hirsutum on dead trunk of pedunculate oak Quercus robur L., collected 10.10.2014, leg. X. DOBRZAŃSKI;

- Wrocław-Wojnów [UTM: XS56], 24.03.2015, 1 exx., ex larvae, cult. Stereum hirsutum on dead hazel Corylus avellana L., collected 15.03.2015, leg. X. DOBRZAŃSKI;

- Obrocz [UTM: FB40], 20.04.2016, 1 ex., ex larvae, cult. Stereum hirsutum on dead branch of oak Quercus sp., collected 16.03.2016, leg. Ł. DAWIDOWICZ;

- Kosobudy [UTM: FB41], 19-29.06.2016, 5 exx., ex larvae, cult. Stereum rugosum on dead hazel Corylus avellana, collected 17.05.2016, leg. Ł. DAWIDOWICZ.

The first locality is an acidophile oak forest (Quercetea robori-petraeae) in the Natura 2000 area of Dąbrowy Janikowskie (PLH020089). The main tree species in the area are pedunculate oak (Quercus robur) and Scots pine (Pinus sylvestris L.), both aged ca. 110 years. Additional tree species are European larch (Larix decidua MILL.) and Norway spruce (Picea abies (L.) H. KARST).

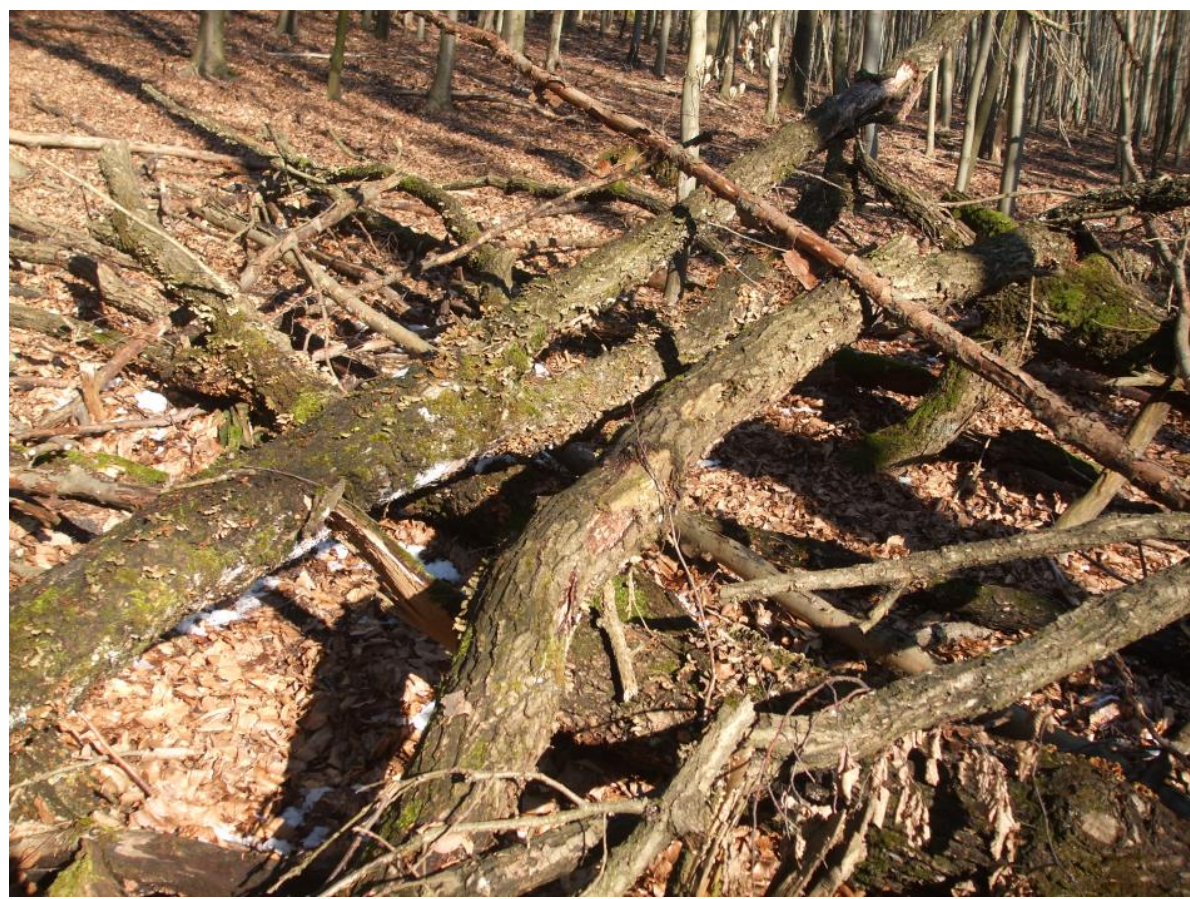

Fig. 2. Dead oak overgrown with sporocarps of Stereum hirsutum - the habitat of Nemapogon gliriella near the Obrocz locality. 


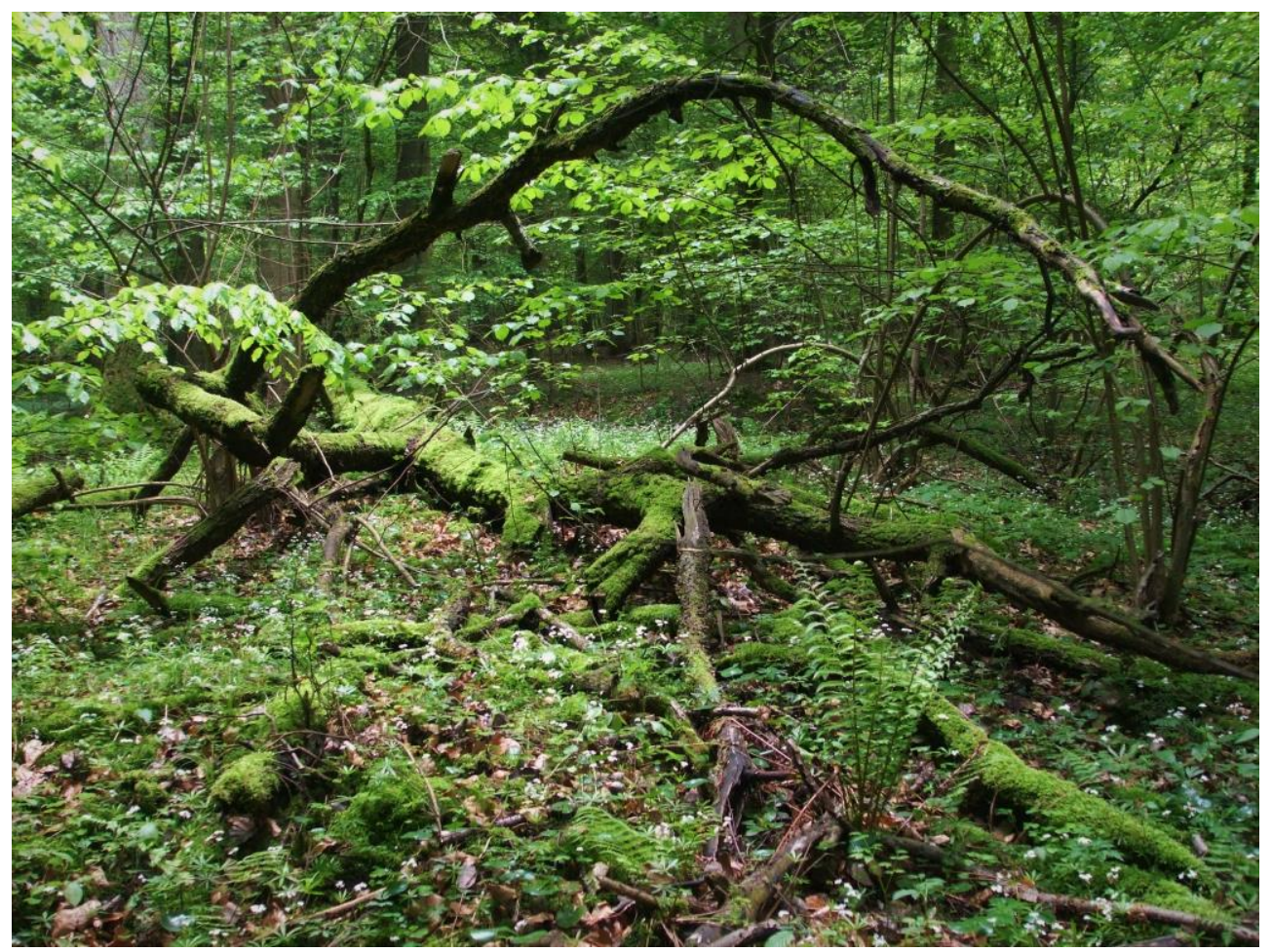

Fig. 3. Habitat of Nemapogon gliriella near the village of Kosobudy.

The second locality is a deciduous forest in the Oder valley within the Wrocław city limits. The main part of this locality consists of hornbeam forest (Tilio-Carpinetum) with isolated pockets of riparian woodland and willow thickets. The tree composition is dominated by oak (ca. 135 years); also present are European hornbeam (Carpinus betulus L.) (ca. 105 years), common ash (Fraxinus excelsior L.) and lime (Tilia sp.), the last two species both aged ca. 135 years.

The last two localities are situated within the Roztocze National Park, established for the protection of the vast areas of forests dominated by European beech (Fagus sylvatica L.) and silver fir (Abies alba MILL.). The Obrocz locality (Fig. 2) is characterized by the dominance of beech and fir, aged ca. 100-180 and 100-160 years, respectively. Further tree species in the area include European hornbeam, Scots pine, pedunculate oak and Norway spruce. The main plant communities are Querco-Fagetea and Dentario glandulosaeFagetum. The Kosobudy locality (Fig. 3) is dominated by silver fir (100-120 years old) and pedunculate oak (60-140 years), with Scots pine, beech, hornbeam, sycamore (Acer pseudoplatanus L.), elm (Ulmus spp.) and other admixed tree species. This area is mainly 
covered by forests of the Tilio-Carpinetum and Dentario glandulosae-Fagetum plant assemblages.

\section{DISCUSSION}

Nemapogon gliriella has been reported from a few central and north European countries, namely, Austria, Germany, the Czech Republic, Slovakia, Slovenia, Switzerland and Sweden (WIMMER 2004, GAEDIKE 2015). Apart from these regions, the species has also been recorded from the Caucasus (Armenia and Georgia), Turkey and the south of the European part of Russia (GAEDIKE 2015) (Fig. 4). In view of its distribution, therefore, the occurrence of $N$. gliriella in Poland was to be expected. The species is probably present in various parts of Poland, especially in deciduous forests with large amounts of dead wood, but has been overlooked during entomological studies because of its concealed lifestyle and, perhaps, the low activity levels of the adult moths. Furthermore, morphological similarities within the genus Nemapogon may also have led to misidentifications of $N$. gliriella with other species.

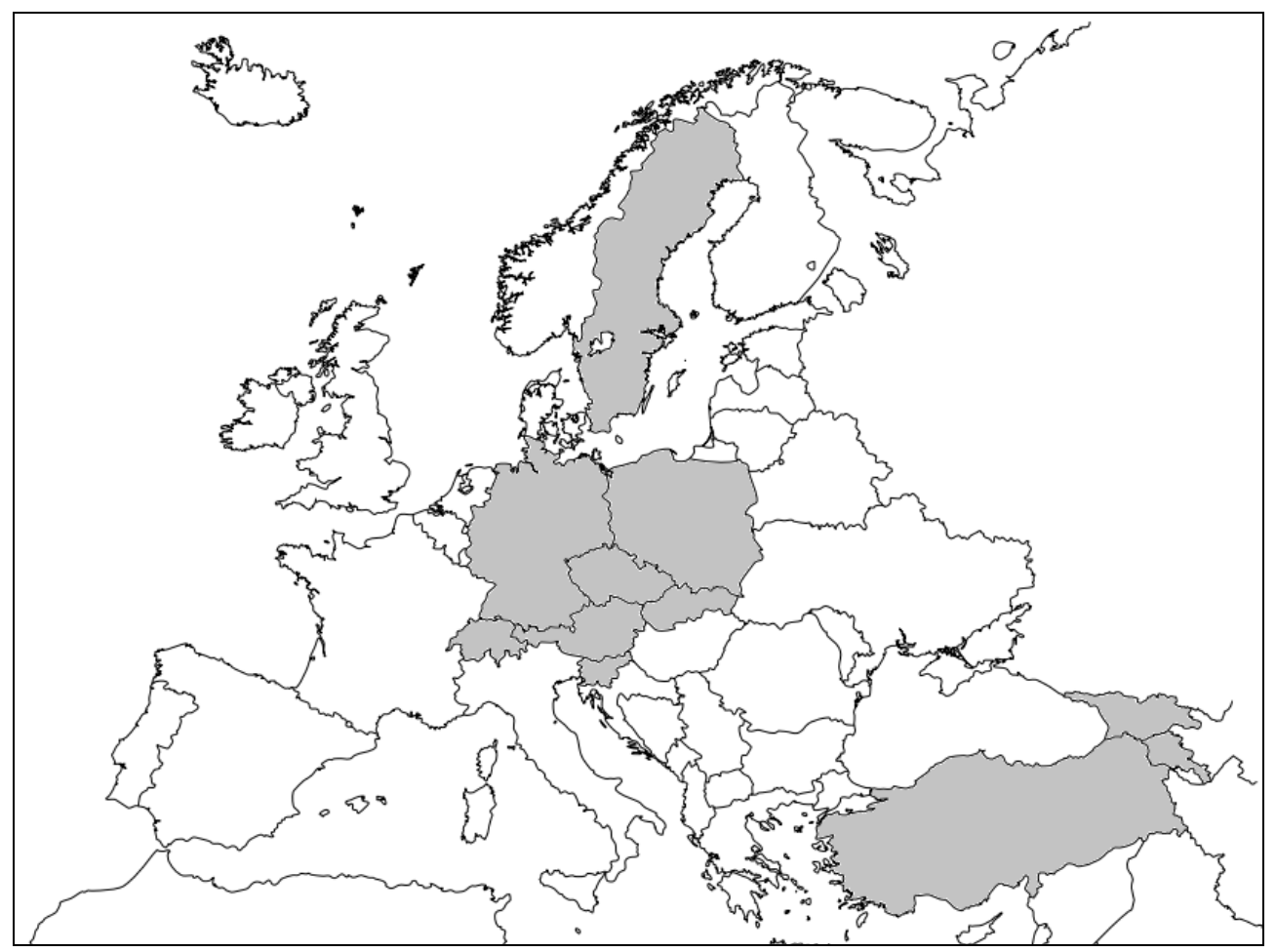

Fig. 4. Current distribution of Nemapogon gliriella in Europe (after GAEDIKE 2015 and authors' own data). 


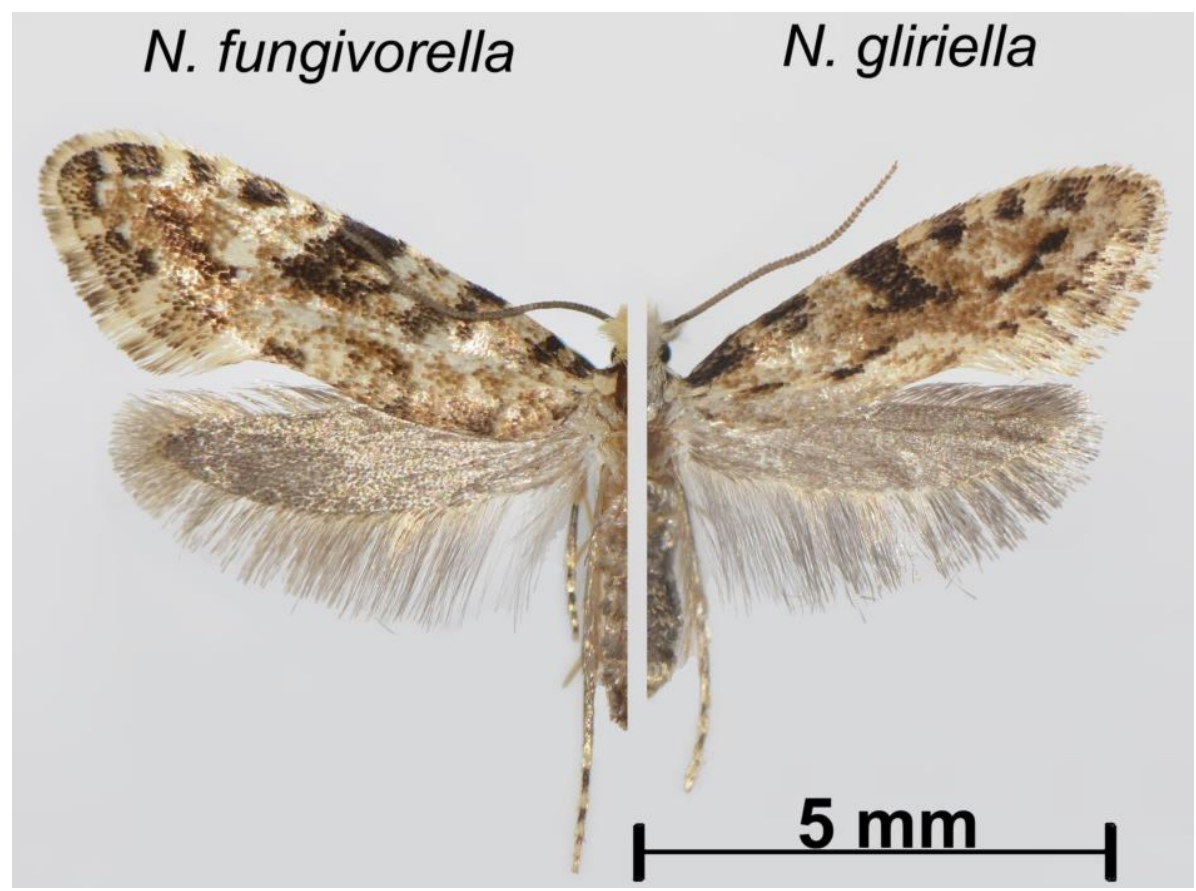

Fig. 5. Comparison of the external morphologies of Nemapogon gliriella and $N$. fungivorella.

Taking the above into consideration, it is possible to distinguish between Nemapogon gliriella and such common species as $N$. granella (LINNAEUS, 1758) or $N$. cloacella (HAWORTH, 1828) based on external morphology. In N. gliriella the ground colour of the forewing is whitish, covered with brown scales, as opposed to the greyish or blackish forewings of the latter two species. Additionally, the head of the adult $N$. gliriella is densely covered with white hairs, in contrast to $N$. granella and $N$. cloacella, the heads of which bear grey and yellow hairs, respectively. $N$. gliriella can be easily confused with Nemapogon fungivorella (BENANDER, 1939) (Fig. 5), but one distinguishing feature is the coloration of the hairs on the head - white in the former species vs. yellowish in the latter. The differences in wing patterns are subtle and related mainly to the shape of the black stripes on the forewings (see details in GAEDIKE 2015). In order to confirm identification, examination of the genitalia is thus recommended. The main difference between the male genitalia of $N$. gliriella and $N$. fungivorella is the length of the phallus: about 3 times longer than the valva vs. slightly longer than the valva, respectively (Fig. 6). Further diagnostic features are the shape of the gnathos arms: angled, divided apically in N. gliriella vs. rounded, not divided apically in $N$. fungivorella, and the length of the digitus: about half the 
length of the valva vs. much longer than the valva, respectively. The female genitalia of both species differ in the shape of the ostium bursae: basally bulb-shaped, with a long, narrow process in N. gliriella (Fig. 7) vs. rounded, without a process in N. fungivorella. More precise descriptions of the genitalia of both species will be found in a number of articles (e.g. ZAGULAJEV 1964, GAEDIKE et al. 2010, GAEDIKE 2015).
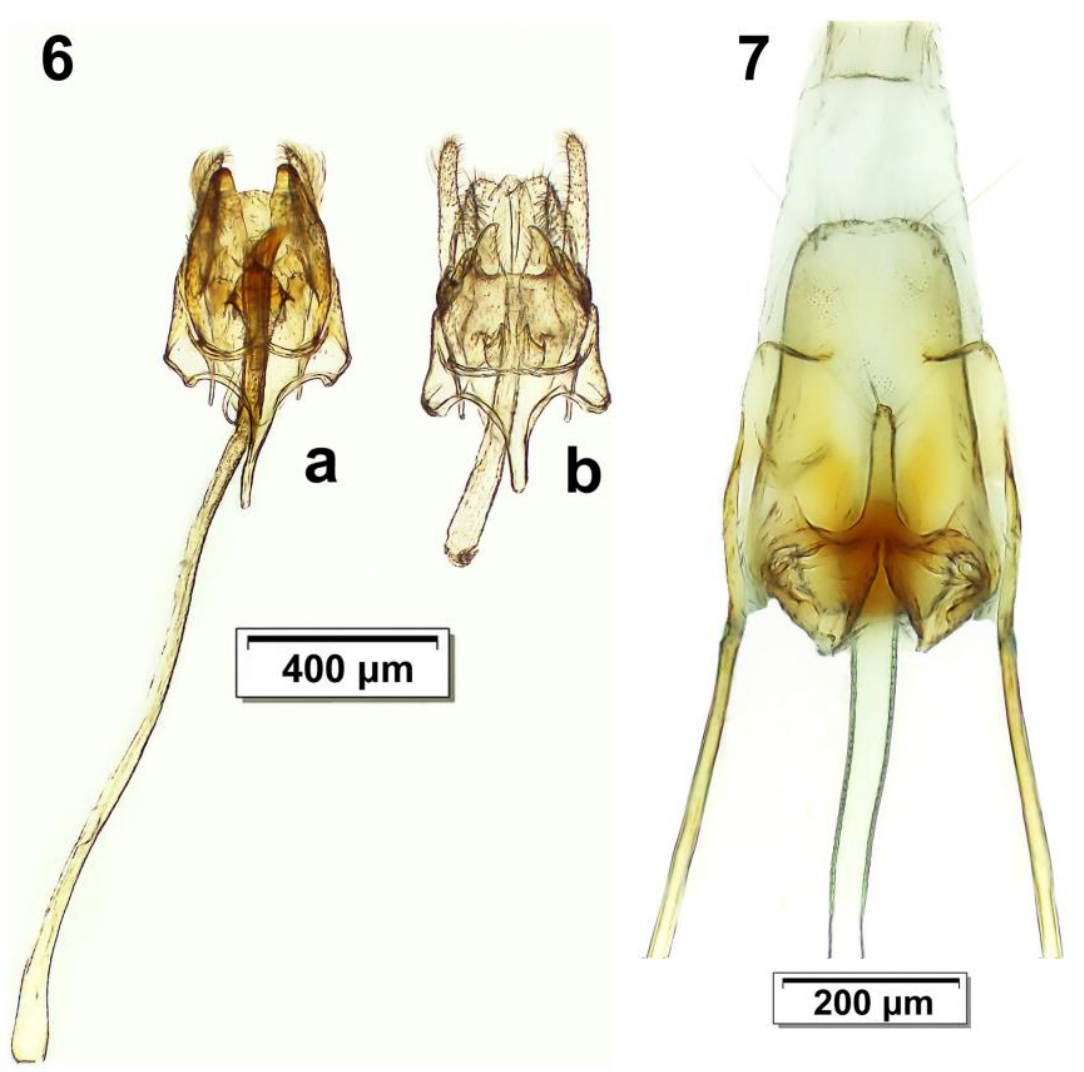

Figs 6, 7. 6 - Male genitalia of Nemapogon gliriella (a) and N. fungivorella (b). 7 - Female genitalia of N. gliriella, fragment.

Apart from the morphological characteristics, knowledge of environmental requirements is of importance for the detection and further identification of tineid moths (JAWORSKI et al. 2014, 2016). Based on literature sources and own data, we conclude this is also true for the two species under discussion here with regard to their fungal hosts: Nemapogon fungivorella is related to the oak specialist polypore Daedalea quercina (L.) 
PERS. (e.g. BENGTSSON et al. 2008, JAWORSKI et al. 2014) while $N$. gliriella has so far been reported from two generalist fungi - Stereum hirsutum and S. rugosum (GAEDIKE 2007, GAEDIKE et al. 2010). Thus, in order to detect these moths in a given area, it may be best to look for their fungal hosts in which caterpillars are feeding, and then take the fruiting bodies to the laboratory for rearing.

The life history of $N$. gliriella is poorly known. Adults have been collected between June and August (GAEDIKE 2015), but data on the number of generations per year is lacking. Caterpillars have been observed feeding on fruiting bodies of Stereum spp. and in dead wood overgrown with fungal hyphae. The presence of larvae inside a fruiting body is betrayed by the clumps of frass granules on its underside (Fig. 8). Pupation takes place inside the feeding substrate and pupal exuviae often remain in situ after the moths have eclosed (Fig. 9). The caterpillars are similar in appearance to those of other Nemapogon species, i.e. a creamy-white body with a light brown head (authors' own observations); nevertheless, the detailed morphology of the larval stages is unknown and will thus require future study.

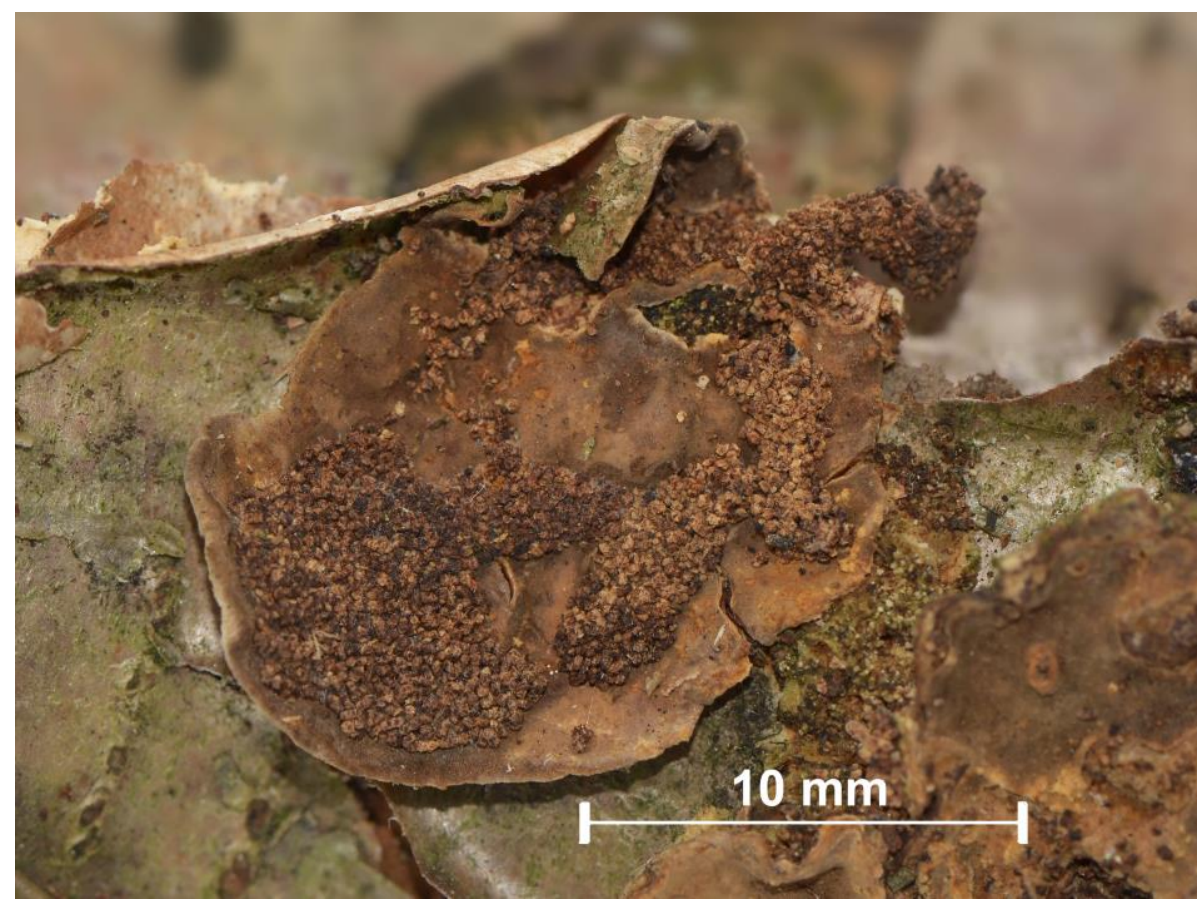

Fig. 8. Fruiting body of Stereum hirsutum covered with frass of Nemapogon gliriella caterpillars. 


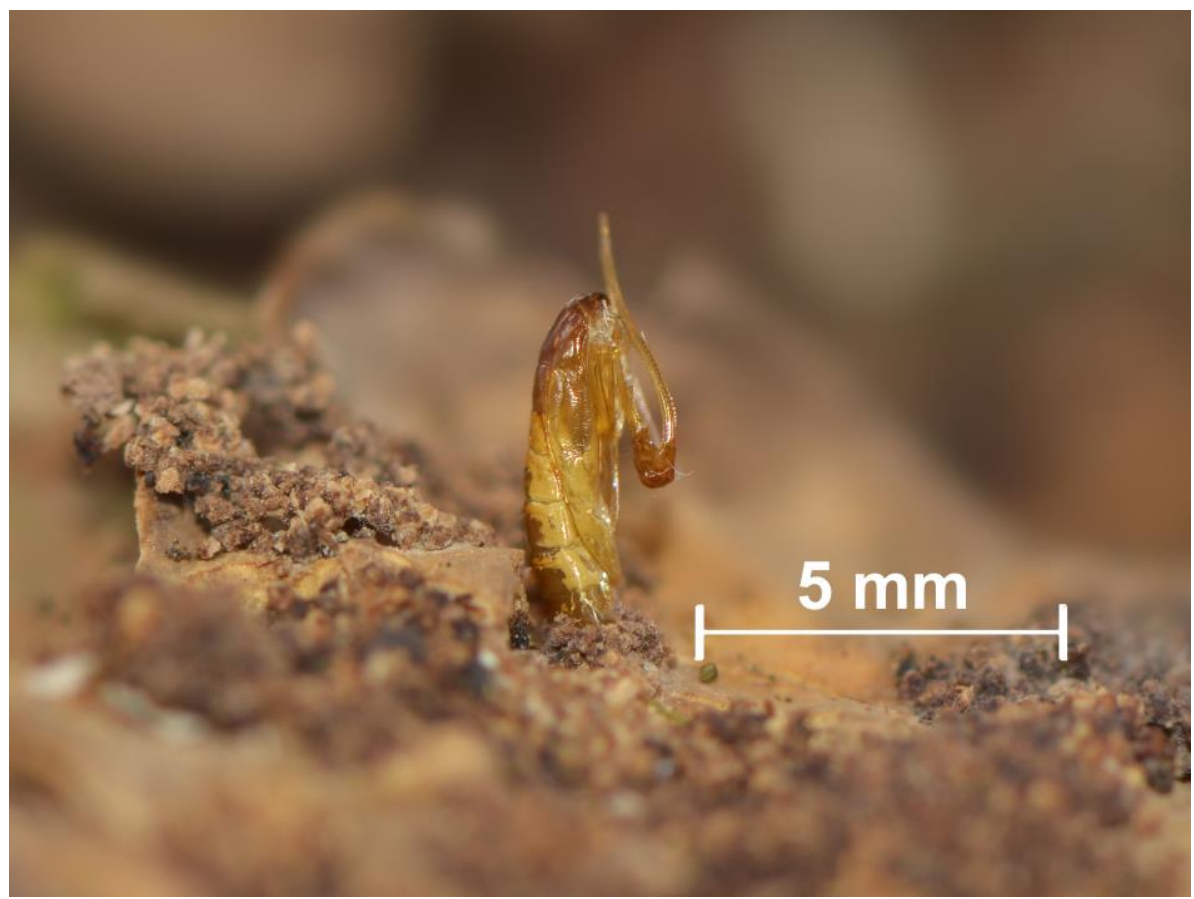

Fig. 9. Pupal exuvium of Nemapogon gliriella protruding from the feeding substrate.

\section{CONCLUSIONS}

Tineidae are one of the most neglected families of Microlepidoptera: this is due mostly to difficulties with their collection and identification. Intensification of field research using appropriate methods will extend our knowledge of the distribution and biology of these moths. It is likely, moreover, that some new species will be recorded, especially among the fungivorous taxa.

\section{REFERENCES}

Bengtsson B.Å., Johansson R., PALmevist G. 2008. Encyclopedia of the Swedish flora and fauna. Lepidopterans: Micropterigidae - Psychidae. ArtDatabanken, SLU, Uppsala. [in Swedish]

GAEDIKE R. 2007. Some new and interesting "Microlepidoptera" from the collection of the Zoologisches Forschungsmuseum Alexander Koenig (ZFMK), Bonn (Lepidoptera: Tineidae, Epermeniidae, Acrolepiidae, Douglasiidae). Bonner zoologische Beiträge 56(1/2): 101-106.

GAEDIKE R. 2015. Microlepidoptera of Europe, vol. 7. Tineidae I: Dryadaulinae, Hapsiferinae, Euplocaminae, Scardiinae, Nemapogoninae and Meessiinae. Brill, Leiden - Boston. 
Gaedike R., Gomboc S., Lasan M. 2010. Zur Kenntnis der Tineidae von Slowenien (Lepidoptera). Acta Entomologica Slovenica 18(2): 87-126.

Jaworski T., Hilszczański J., Plewa R., Szczepkowski A. 2014. Fungus moths (Lepidoptera, Tineidae) of the Białowieża Forest. Polish Journal of Entomology 83(1): 5-21.

JAwOrski T., Plewa R., HilszcZAŃSKi J., SzCZEPKOwSKi A., HoraK J. 2016. Saproxylic moths reveal complex within-group and group-environment patterns. Journal of Insect Conservation 20(4): 677-690.

ROBINSON G.S. 2009. Biology, distribution and diversity of tineid moths. Southdene Sdn Bhd, Kuala Lumpur and Natural History Museum, London.

ŚLıwiŃSKi Z. 2000. Tineidae. [in:] J. Buszko, J. NowaCKi (eds.). Polish Entomological Monographs, Vol. 1. The Lepidoptera of Poland. A Distributional Checklist. Polish Entomological Society, Poznań - Toruń, 17-19.

WiMMER J. 2004. Lepidopterologische Notizen aus Oberösterreich - 7 (Insecta: Lepidoptera). Beiträge zur Naturkunde Oberösterreichs 13: 453-459.

ZAGULAJEV A.K. 1964. Fauna of the USSR, new series, vol. 86: Insects, lepidopterans. Fungus moths (Tineidae), subfamily Nemapogoninae. Nauka, Moskva - Leningrad. [in Russian]

Received: 22 March 2016

Accepted: 9 September 2016 